\title{
Knowledge, attitude and practice of contraception by female junior secondary school students in an urban community of Oyo-state, South west, Nigeria
}

\author{
Ajibola Idowu ${ }^{1 *}$, Olatayo A. Aremu ${ }^{1}$, Funmito O. Fehintola ${ }^{2}$, Gbenga O. Popoola ${ }^{3}$
}

\begin{abstract}
${ }^{1}$ Department of Community Medicine, Bowen University Teaching Hospital, Ogbomoso, Oyo State, Nigeria ${ }^{2}$ Department of Community Health, Obafemi Awolowo University Teaching Hospital, Ile-Ife, Osun State, Nigeria ${ }^{3}$ Department of Community Health, University of Ilorin Teaching Hospital, Ilorin, Kwara State, Nigeria
\end{abstract}

Received: 16 August 2017

Accepted: 16 September 2017

\author{
*Correspondence: \\ Dr. Ajibola Idowu, \\ E-mail: idajibola@yahoo.com
}

Copyright: (c) the author(s), publisher and licensee Medip Academy. This is an open-access article distributed under the terms of the Creative Commons Attribution Non-Commercial License, which permits unrestricted non-commercial use, distribution, and reproduction in any medium, provided the original work is properly cited.

\begin{abstract}
Background: Unintended pregnancies resulting in several maternal morbidities and mortalities are still a major public health challenge in most parts of the world. Female secondary school students are particularly vulnerable due to their engagement in unsafe sex and low uptake of family planning services. The study assessed respondents' level of knowledge on, attitude to and practice of family planning.

Methods: A cross-sectional study was conducted among 240 consenting female junior secondary school students in two public schools in Ogbomoso, South West Nigeria. Multi-stage sampling method was employed in recruiting the study participants and facilitated self-administered semi-structured questionnaire used for data collection. Descriptive statistics was done and Chi-square test used to compare categorical variables. The level of statistical significance was set at $\mathrm{p}<0.05$.

Results: The mean age of the respondents was $13.6 \pm 2.3$ and $69.5 \%$ of them were early adolescents (10-13years of age). Almost all $(92.3 \%)$ of the respondents were aware of family planning but only $58.1 \%$ and $55.3 \%$ of them had good knowledge on and positive attitudes towards family planning respectively. In all, $64.0 \%$ of the sexually active respondents had ever used family planning. Condom was the commonest family planning method ever used; reported by $65.0 \%$ of those who had ever used family planning. Fear of side effects was the main reason among non-users.

Conclusions: Family planning uptake among sexually active female students is low in Southwest Nigeria. There is urgent need for aggressive awareness campaigns to improve the knowledge score and attitude of students to family planning in Nigeria.
\end{abstract}

Keywords: Adolescents, Attitude, Family planning, Knowledge, Secondary schools

\section{INTRODUCTION}

Globally, unintended pregnancies resulting in abortions and myriad abortion-related complications is now a major reproductive and public health challenge. This problem affects millions of women worldwide and has been identified as one of the leading causes of maternal morbidities and mortalities. According to World Health Organization (WHO), about 16 million girls aged 15-19 and about one million girls less than 15 years of age give birth every year while about three million girls aged 1519 undergo unsafe abortion yearly. ${ }^{1}$ Moreover, about 75 million of the estimated 180-200 million pregnancies that occur annually in the world are unintended and most of these pregnancies occur in adolescents. ${ }^{2}$ On the average, 
56 million induced abortions occur worldwide each year. ${ }^{3}$ Regrettably, an estimated 2.2 million unintended pregnancies occur annually among adolescents in subSaharan Africa and almost 60 percent of unsafe abortions in Africa are among women aged 15-24 years. ${ }^{4}$

In a study among in-school adolescents in eight African countries by Peltzer K, not less than $27.3 \%$ of the respondents had experienced sexual debut before age 15.5 In Nigeria, not less than $60 \%$ of the 600,000 induced abortions occurring annually are found among adolescents while 250 out of 1000 adolescent pregnancies end in unsafe abortion. ${ }^{6}$

Reproductive health indices for Nigeria are still staggering in spite of several efforts from governmental and non-governmental agencies. The 2013 Demographic and Health Survey for Nigeria revealed that only $10 \%$ of the currently married women were using modern contraceptive methods. ${ }^{7}$ This could partly explain the high maternal mortality rate of 576 deaths/100,000 live births recorded in the survey and could be part of the reasons while Nigeria was among the countries that failed to meet the Millennium development goals.

Most Nigerian studies on family planning had revealed high contraceptive knowledge among secondary school students. However, contraceptive utilization rate among this group of people has remained worrisomely low in spite of high sexual activities being practiced by them. In a study by Chima et al, $67.5 \%$ of senior secondary school students in Lagos, Nigeria had correct knowledge on family planning but only $31.1 \%$ of the sexually active respondents had ever used any form of family planning. ${ }^{8}$ Moreover, Orji and Esimai in a study conducted in Ilesha, South-west Nigeria, revealed that $50 \%$ of the secondary school students surveyed were sexually active but $86.7 \%$ of them did not use any contraceptive method. ${ }^{9}$ Also, a study conducted among 1500 students in two secondary schools in Lagos State, Nigeria, revealed that $77 \%$ of the respondents were knowledgeable about contraception but only $3 \%$ of them had been using family planning prior to the survey. ${ }^{10}$ In another study conducted in Nigeria, only $34.5 \%$ of the 400 adolescents that were randomly selected used family planning methods. ${ }^{11}$

In 2011, the WHO and United Nations Population Fund (UNFPA) jointly published a guideline to prevent early pregnancies; increasing the use of contraception by adolescents was one of recommended key strategies. Thus, this study aimed at assessing knowledge, attitude and practice of secondary school students in Ogbomoso on family planning. The study focused on female students in junior classes. This is because most students in this category have been shown to engage in unsafe sex practices thereby increasing their vulnerability to unwanted pregnancies and unsafe abortion. ${ }^{9}$ Studies such as the current one can provide useful information that could help policy makers to revamp family planning services for secondary school students in Nigeria.

\section{METHODS}

The study was conducted among junior secondary school students in two selected public schools in Ogbomoso North Local Government Area (LGA) of Oyo State, South West Nigeria. The LGA has ten (10) public secondary schools. ${ }^{12}$

Cross-sectional study design was employed.

\section{Sample size calculation}

The required sample size was calculated using Leslie Kish sample size formula for estimating single proportion.

$\mathrm{n}=\mathrm{Z}^{2} \alpha \mathrm{pq} / \mathrm{d}^{2}$

Where;

$\mathrm{n}=$ minimum sample size

$\mathrm{Z} \alpha=$ standard relative deviate at $95 \%$ confidence level $=1.96$

$\mathrm{P}=$ proportion of respondents using modern contraceptive method.

Based on findings from similar studies in Nigeria, at least $16.0 \%$ of our respondents were expected to have used a modern contraceptive method. ${ }^{13}$ The tolerable margin of error was set at 0.05 and correction for non-response made. Overall, a minimum sample size of 230 was estimated for the study.

\section{Inclusion criteria}

Fully registered female students in junior classes who had being in the school for at least six months and gave their assents/consents were allowed to participate in the study.

\section{Exclusion criteria}

Students with significant physical or mental handicap, which could affect their ability to respond validly to our questions, were excluded from the study.

\section{Sampling technique}

Multi-stage sampling method was used to select eligible respondents over a period of one month (April 2017). In the first stage, two co-educational public secondary schools were selected by balloting from the list of ten government secondary schools within the LGA.

The two selected schools included Anglican and Ori-Oke Grammar chools, Ogbomoso. The number of respondents selected per school was proportionate to their population sizes using the formula, Number of students in a school divided by total number of students in the two selected schools, multiplied by the sample size (240). 
Stage two involved selection of classes from each level of JSS 1-3; the two schools visited had more than one classes per class-level; two of such classes were selected by balloting. Stage three involved selecting eligible female respondents from the selected classes; a proportionate sample was taken from the selected classes based on their sizes and pre-determined number of respondents allotted to the school. Respondents from selected classes were selected using systematic sampling technique; the sampling interval was calculated based on the number of students in the class and the number of respondents to be selected from the class. The first participant was selected by balloting.

\section{Data collection method and instrument}

Data were collected within four weeks (April 2017) using a facilitated self-administered and semi-structured questionnaire developed based on review of previous studies. Questions were asked on respondents' sociodemographic characteristics, their awareness about, knowledge on, attitude to and practice of family planning.

Ten medical students of Bowen University Teaching Hospital were trained on how to administer questionnaire to youths and adolescents and assisted in data collection. Eligible respondents from selected schools were gathered in halls provided by the respective schools; this was done in order not to disrupt the lecture-schedule of the students. The purpose of the study was reiterated as this has been explained in the consent/assent form given to them a day before the survey.

Questionnaires were distributed and the research assistants moved round the hall to facilitate the questionnaire completion process. Spaces were created between the respondents and they were encouraged to give their honest and independent answers.

\section{Pre-testing}

The instrument was pretested among 50 female students from a secondary school in Ogbomoso South LGA (Adeniran Memorial Grammar School, Ogbomoso).

The school was a co-educational public school; similar to the schools used for the main study. The exercise helped in assessing appropriateness of the questions in eliciting desired responses. Ambiguous questions were re-phrased or removed in line with study objectives.

\section{Ethical consideration}

Approval for the study was obtained from the Ethical Review Committee of the Bowen University Teaching Hospital, Ogbomoso and permission obtained from authorities of the participating schools. Written assents/consents were also obtained from study participants.
Participation was entirely voluntary, confidentiality was ensured; codes rather than participants' names were used as personal identifiers and data were stored in a computer that was only accessible to the principal investigator.

\section{Measures}

Knowledge on family planning: four questions were asked to assess the knowledge of the students on family. Correct answer to each of the questions attracted 2 points, thus the respondents were rated over eight points; a score of five or less was categorized as poor knowledge while a score of at least five points was classified as good knowledge

\section{Attitude to family planning}

Four statements were positively phrased and used to assess respondents' attitude towards family planning. Response to each question was rated using Likart scale ranging from strongly agreed (5 points) to strongly disagree (1 point).

Each respondent was rated over 20 points; those who scored less than 10-points were categorized as having negative attitudes to family planning practice.

\section{Family planning practice}

This was defined as respondents who had experienced sex and had ever used any form of modern contraceptive methods

\section{Data management}

Each questionnaire was cross-checked daily on the field to ensure accurate data collection before the data were entered into Statistical Package for Social Sciences (SPSS, Version 21.0) for analysis. Data were summarized using proportions, means and standard deviation and were presented using Tables and pie-charts. Chi-square test was used to compare categorical variables and the level of statistical significance set $\mathrm{p}<0.05$.

\section{RESULTS}

A total of 260 questionnaires were administered but 240 of them were returned fully completed giving a response rate of $92.3 \%$. Table 1 shows that the mean age of the respondents was $13.6 \pm 2.3$. Majority $(69.5 \%)$ of the respondents were early adolescents (10-13 years of age), most $(39.0 \%)$ of them were in Junior secondary school (JSS) one while more than three-quarter $(89.4 \%)$ of them practiced Christian religion.

Whereas $5.3 \%$ of the respondents lived with their fathers, more than three-quarter $(76.8 \%)$ of them lived with both parents. Most mothers $(44.3 \%)$ attained secondary education while fathers mostly had tertiary education $(45.2 \%)$. 
Table 1: Socio-demographic characteristics of the respondents.

\begin{tabular}{|c|c|c|}
\hline Variable & Frequency N=246 & Percentage \\
\hline \multicolumn{3}{|l|}{ Age (years) } \\
\hline $10-13$ & 171 & 69.5 \\
\hline $14-16$ & 67 & 27.2 \\
\hline $17-19$ & 5 & 2.0 \\
\hline$\geq 20$ & 3 & 1.2 \\
\hline Mean \pm SD & $13.6 \pm 2.3$ & \\
\hline \multicolumn{3}{|l|}{ Class level } \\
\hline JSS 1 & 97 & 39.4 \\
\hline JSS 2 & 87 & 35.4 \\
\hline JSS 3 & 62 & 25.2 \\
\hline \multicolumn{3}{|l|}{ Religion } \\
\hline Christianity & 220 & 89.4 \\
\hline Islam & 21 & 8.5 \\
\hline Traditional & 5 & 2.1 \\
\hline \multicolumn{3}{|l|}{ Living situation } \\
\hline Father only & 13 & 5.3 \\
\hline Mother only & 29 & 11.8 \\
\hline Both parents & 189 & 76.8 \\
\hline Siblings/guardian & 15 & 6.1 \\
\hline \multicolumn{3}{|c|}{ Mother's highest education } \\
\hline No formal education & 17 & 6.9 \\
\hline Primary education & 24 & 9.8 \\
\hline Secondary education & 109 & 44.3 \\
\hline Tertiary education & 96 & 39.0 \\
\hline \multicolumn{3}{|c|}{ Father's highest education } \\
\hline No formal education & 21 & 8.5 \\
\hline Primary education & 20 & 8.1 \\
\hline Secondary education & 94 & 38.2 \\
\hline Tertiary education & 111 & 45.2 \\
\hline \multicolumn{3}{|c|}{ Number of children belonging to the parents } \\
\hline $1-4$ & 165 & 67.1 \\
\hline$\geq 5$ & 81 & 32.9 \\
\hline \multicolumn{3}{|c|}{ Educational sponsorship } \\
\hline Father only & 29 & 11.8 \\
\hline Mother only & 25 & 10.2 \\
\hline Both parent & 187 & 76.0 \\
\hline Siblings/guardian & 5 & 2.0 \\
\hline
\end{tabular}

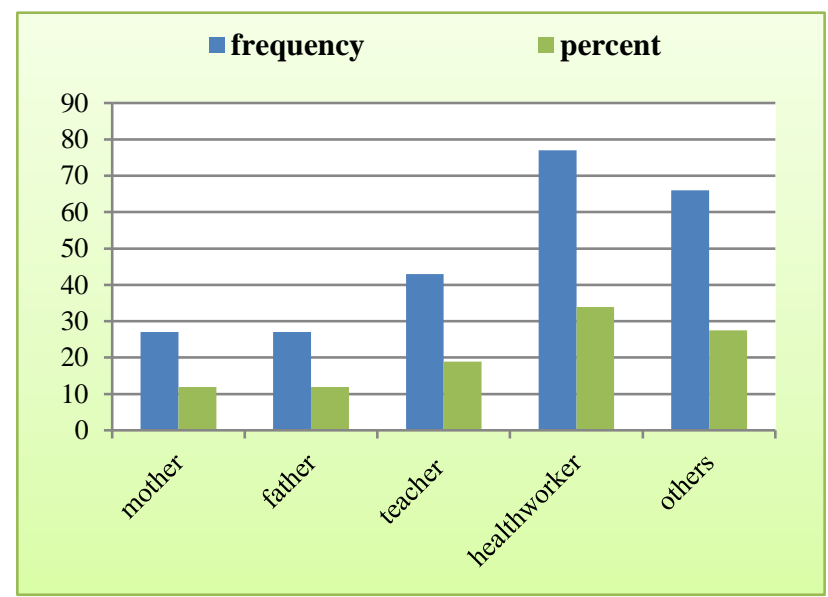

Figure 1: Respondents' sources of information on family planning.
Most $(67.1 \%)$ of the respondents were from households with family sizes ranging from one to four while $76.0 \%$ of them had their educations jointly sponsored by both parents

Table 2: Awareness, knowledge and attitude of respondents to family planning.

\begin{tabular}{|lll|}
\hline Variables & Frequency & Percentage \\
\hline Ever heard of family planning & & \\
\hline Yes & 227 & 92.3 \\
\hline No & 19 & 7.7 \\
\hline Source of information & & \\
\hline Mother & 27 & 11.9 \\
\hline Father & 27 & 11.9 \\
\hline Teacher & 43 & 18.9 \\
\hline Friends & 12 & 5.3 \\
\hline Internet & 12 & 5.3 \\
\hline Books/magazine & 21 & 9.2 \\
\hline Health workers & 77 & 33.9 \\
\hline Radio/tv & 8 & 3.6 \\
\hline Knowledge on why people use family planning \\
\hline To enjoy sex & 34 & 15.0 \\
\hline To prevent unwanted pregnancy & 117 & 51.5 \\
\hline To prevent sexually transmitted & 37 & 16.3 \\
\hline infections & & \\
\hline Don't know & 39 & 17.2 \\
\hline Total & 227 & 100.0 \\
\hline Who should be using family planning & \\
\hline Married women only & 115 & 0.7 \\
\hline Older people only & 35 & 15.4 \\
\hline Those engaging in premarital sex & 46 & 20.3 \\
\hline Don't know & 31 & 13.6 \\
\hline Total & 227 & 100.0 \\
\hline Overall knowledge score & & \\
\hline Good & 143 & 58.1 \\
\hline Poor & 103 & 41.9 \\
\hline Attitude to family planning & & \\
\hline Good & 136 & 55.3 \\
\hline Poor & 110 & 44.7 \\
\hline & & \\
\hline & & \\
\hline & & \\
\hline & & \\
\hline
\end{tabular}

As shown in Table 2, almost all the respondents (92.3\%) had heard of family planning with health workers being the commonest source of information (33.9\%, Figure 1).

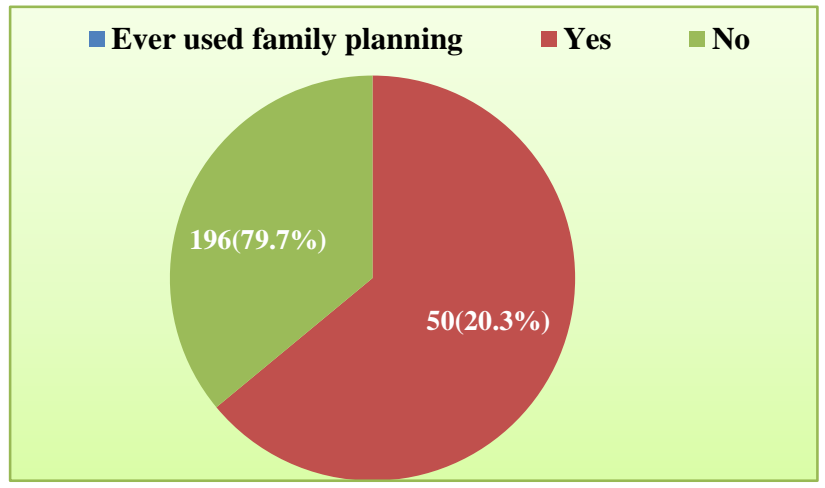

Figure 2: Proportion of respondents who had ever had sex. 
Figure 2 shows that $20.3 \%$ of the respondents had experienced sex before the survey. However, not less than $70 \%$ of them had their sexual debuts when they were $10-14$ years of age (Table 3 ).

Table 3: Practice of respondent on family planning.

\begin{tabular}{|c|c|c|}
\hline Variable & $\begin{array}{l}\text { Frequency } \\
\mathrm{N}=246\end{array}$ & Percentage \\
\hline \multicolumn{3}{|l|}{ Age at sexual debut } \\
\hline$<10$ & 3 & 6.0 \\
\hline $10-14$ & 35 & 70.0 \\
\hline $15-19$ & 10 & 20.0 \\
\hline$>20$ & 2 & 4.0 \\
\hline \multicolumn{3}{|c|}{ Types of family planning ever used $(n=32)$} \\
\hline Condom & 21 & 65.2 \\
\hline IUCD & 1 & 3.2 \\
\hline Injectables & 1 & 3.2 \\
\hline Emergency contraception & 6 & 18.8 \\
\hline Ora pills & 3 & 9.4 \\
\hline \multicolumn{3}{|c|}{ Reasons for non-use of family planning $(n=18)$} \\
\hline Fear of side effects & 8 & 44.0 \\
\hline $\begin{array}{l}\text { Family planning is not a } \\
\text { good thing for young people }\end{array}$ & 4 & 22.0 \\
\hline $\begin{array}{l}\text { I don't think I am at risk of } \\
\text { pregnancy }\end{array}$ & 2 & 11.0 \\
\hline $\begin{array}{l}\text { My partner doesn't like the } \\
\text { idea of using it }\end{array}$ & 3 & 17.0 \\
\hline It is too expensive for me & 1 & 6.0 \\
\hline \multicolumn{3}{|c|}{ Currently using any family planning method $(n=32)$} \\
\hline Yes & 12 & 37.5 \\
\hline No & 20 & 62.5 \\
\hline \multicolumn{3}{|c|}{ Future intention of using family planning $(n=227)$} \\
\hline Yes & 200 & 88.1 \\
\hline No & 27 & 11.9 \\
\hline
\end{tabular}

More than half $(51.5 \%)$ of the respondents who had heard of family planning believed that it can prevent unwanted pregnancies. Meanwhile, $50.7 \%$ of them believed that family planning is reserved for married couple only. In all, more than half $(58.1 \%$ and $55.3 \%)$ of our respondents had good knowledge score on and good attitudes to family planning.

Thirty-two (64.0\%) of the sexually active respondents had used family planning methods at one time or the other (Figure 2). Condom was the most commonly used method; used by $65.2 \%$ of the respondents.

Only $37.5 \%$ of the respondents who had ever used family planning were current users. However, fear of side effects was the most common reason (44.0\%) among non-users. Nonetheless, $200(88.1 \%)$ of all the respondents who had ever heard of family planning indicated future intentions to use any of the modern methods (Table 3).

In Table 4, none of the variables was significantly associated with practice of family planning among the students interviewed.
Table 4: Factors influencing use of family planning among the respondents.

\begin{tabular}{|c|c|c|c|c|c|}
\hline \multirow{3}{*}{ Variable } & \multicolumn{5}{|c|}{$\begin{array}{l}\text { Use of family planning } \\
\text { methods }\end{array}$} \\
\hline & Yes & No & Total & $\chi^{2}$ & $\begin{array}{l}p \\
\text { value }\end{array}$ \\
\hline & n $(\%)$ & n $(\%)$ & $\mathbf{N}$ & & \\
\hline \multicolumn{6}{|c|}{ Age group (years) } \\
\hline $10-14$ & $\begin{array}{l}34 \\
(19.9)\end{array}$ & $\begin{array}{l}137 \\
(80.1)\end{array}$ & 171 & \multirow{3}{*}{$1.771^{\mathrm{Y}}$} & \multirow{3}{*}{0.413} \\
\hline $15-19$ & $\begin{array}{l}13 \\
(18.1)\end{array}$ & $\begin{array}{l}59 \\
(81.9)\end{array}$ & 72 & & \\
\hline $20-25$ & $\begin{array}{l}2 \\
(66.7)\end{array}$ & $\begin{array}{l}1 \\
(33.3)\end{array}$ & 3 & & \\
\hline \multicolumn{6}{|l|}{ Class level } \\
\hline JSS 1 & $\begin{array}{l}22 \\
(22.7)\end{array}$ & $\begin{array}{l}75 \\
(77.3)\end{array}$ & 97 & \multirow{3}{*}{0.867} & \multirow{3}{*}{0.648} \\
\hline JSS 2 & $\begin{array}{l}15 \\
(17.2)\end{array}$ & $\begin{array}{l}72 \\
(82.8)\end{array}$ & 87 & & \\
\hline JSS 3 & $\begin{array}{l}12 \\
(19.4)\end{array}$ & $\begin{array}{l}50 \\
(80.6)\end{array}$ & 62 & & \\
\hline \multicolumn{6}{|l|}{ Religion } \\
\hline Christianity & $\begin{array}{l}43 \\
(19.5)\end{array}$ & $\begin{array}{l}177 \\
(80.5)\end{array}$ & 220 & \multirow{3}{*}{$0.145^{\mathrm{Y}}$} & \multirow{3}{*}{0.930} \\
\hline Islam & $\begin{array}{l}5 \\
(22.7)\end{array}$ & $\begin{array}{l}17 \\
(77.3)\end{array}$ & 22 & & \\
\hline Traditional & $\begin{array}{l}1 \\
(25.0)\end{array}$ & $\begin{array}{l}3 \\
(75.0)\end{array}$ & 4 & & \\
\hline \multicolumn{6}{|c|}{ Primary caregiver } \\
\hline Father only & $\begin{array}{l}3 \\
(23.1)\end{array}$ & $\begin{array}{l}10 \\
(76.9)\end{array}$ & 13 & \multirow{3}{*}{$0.789^{\mathrm{Y}}$} & \multirow{3}{*}{0.852} \\
\hline $\begin{array}{l}\text { Mother } \\
\text { only }\end{array}$ & $\begin{array}{l}8 \\
(27.6)\end{array}$ & $\begin{array}{l}21 \\
(72.4)\end{array}$ & 29 & & \\
\hline Both parent & $\begin{array}{l}36 \\
(19.0)\end{array}$ & $\begin{array}{l}153 \\
(81.0)\end{array}$ & 189 & & \\
\hline $\begin{array}{l}\text { Siblings/ } \\
\text { Guardians }\end{array}$ & $\begin{array}{l}2 \\
(13.3)\end{array}$ & $\begin{array}{l}13 \\
(86.7)\end{array}$ & 15 & & \\
\hline \multicolumn{6}{|c|}{ Mothers highest educational level } \\
\hline $\begin{array}{l}\text { None } \\
\text { formal }\end{array}$ & $\begin{array}{l}4 \\
(23.5)\end{array}$ & $\begin{array}{l}13 \\
(76.5)\end{array}$ & 17 & \multirow{3}{*}{$0.168^{\mathrm{Y}}$} & \multirow{3}{*}{0.983} \\
\hline Primary & $\begin{array}{l}6 \\
(25.0)\end{array}$ & $\begin{array}{l}18 \\
(75.0)\end{array}$ & 24 & & \\
\hline Secondary & $\begin{array}{l}21 \\
(19.3)\end{array}$ & $\begin{array}{l}88 \\
(80.7)\end{array}$ & 109 & & \\
\hline Tertiary & $\begin{array}{l}18 \\
(18.8\end{array}$ & $\begin{array}{l}78 \\
(81.3)\end{array}$ & 96 & & \\
\hline
\end{tabular}

\section{Knowledge on family planning}

\begin{tabular}{|llllll|}
\hline Good & 26 & 117 & 143 & & \\
& $(18.2)$ & $(81.8)$ & 143 & 0.521 & 0.260 \\
\cline { 1 - 3 } Poor & 23 & 80 & 103 & & \\
\hline
\end{tabular}

Attitude to family planning

\begin{tabular}{|llllll|}
\hline Good & 23 & 113 & 136 & & \\
& $(16.9)$ & $(83.1)$ & & 1.724 & 0.189 \\
\hline Poor & 26 & 84 & 110 & & \\
\hline
\end{tabular}

\section{DISCUSSION}

Fifty $(20.3 \%)$ of our respondents had experienced sex before the survey. This is in consonance with findings 
from other studies. For instance, Anochie and Kepeme reported that $25.7 \%$ of the secondary school students surveyed in Port Harcourt had had sex before the survey. ${ }^{14}$ Also, Gail et al, reported that $34 \%$ of secondary school students in Plateau State, North Central Nigeria were sexually active. ${ }^{15}$ Ajuwon et al also reported the prevalence of sexual activities among secondary school students in three North-eastern states, Nigeria as $13 \% .{ }^{16}$ On the contrary, Orji and Esimai reported that $50 \%$ of secondary school students in Ilesha, South West Nigeria were sexually active. ${ }^{9}$

Meanwhile, the said study was conducted among students attending coaching classes as opposed to the current study which was carried out in public school settings. Some students attending coaching classes in Nigeria might have finished their secondary education and just attending coaching classes in preparation for their joint examinations. Such students might have detached themselves from the strong parental and teacher influence which are often restrictive and protective against practice of sexual activities among young people.

Almost $70.0 \%$ of the sexually active respondents had their sexual debuts when they were 10-14 years of age. Nnebue et al, in a similar study in Lagos found that the mean age of sexual debut was $14 \pm 1.2$ and 13.4 $\pm 1.5 .^{17}$ Ajuwon et al also revealed that the age of sexual debut was 15. 8 years among North Eastern Secondary school students. ${ }^{16}$

Not less than $92.3 \%$ of the respondents were aware of family planning but only $58.1 \%$ of them had good knowledge score. These findings agree with previous studies. For example, Adetokunbo et al, reported that $77 \%$ of the students surveyed had contraceptive knowledge while Utuk et al reported that $75.6 \%$ of the adolescents surveyed were aware of contraception. ${ }^{10,13}$ Also, a study by Idonije et al, reported that 42.3 and $60 \%$ of male and female secondary school students in Ekpoma, Nigeria had good knowledge on family planning. ${ }^{18}$

In the current study, more than half $(55.3 \%)$ of the students interviewed had positive attitude to family planning and $88.1 \%$ of them indicated intention to use in their future sexual encounters. Although no statistically significant relationship existed between respondents' attitude towards family and utilization in the current study, previous studies had established that those who approved of family planning are more likely to use them. ${ }^{19}$

Although, $64.0 \%$ of the sexually active respondents in the current study had ever used family planning, only $37.5 \%$ were current users. This agrees with findings from Ilesha study by Orji and Esimai which reported that $86.7 \%$ of the sexually active respondents did not use family planning. ${ }^{9}$ Our finding also compares with that of Adetokunbo et al which shows that $95 \%$ of female students in three secondary schools in Lagos did not use family planning. ${ }^{10}$

Similarly, Iniabisi et al, in a study in Akwa Ibom, revealed that only $34.5 \%$ of the adolescents surveyed used family planning. ${ }^{11}$ In the current study, condom was the commonest family planning method ever used; utilized by $65.2 \%$ of the sexually active respondents. This finding agrees with previous studies..$^{10,13}$

Due to time constraints and limited financial resources, the study was conducted in two public schools out of many public and private schools in Ogbomoso, the external validity of the study may have been compromised but the fact that probability (multi-stage) sampling method was employed in selection of study participants, the results from this study could be said to be accurate and reliable.

\section{CONCLUSION}

Knowledge on, attitude towards and practice of family planning among female junior secondary school students in Ogbomoso is still low. This calls for an aggressive awareness campaigns to raise the level of knowledge of students on family planning.

Government could partner the media houses to make information dissemination more effective. Policy makers working in the field of family planning should engage the social-media more in reaching the youths with family planning-related information.

There is also a need to incorporate sex education and contraception into the school curriculum in Nigeria. This will enable students to have easy access to information needed for responsible family planning decisions thereby reducing the rate of occurrence of unwanted pregnancies, possibilities of unsafe abortion and ultimately reducing maternal mortality rate in Nigeria.

Moreover, there is a dare need for a non-judgmental and youth friendly reproductive/family planning services. This will assist in providing family planning and reproductive health services to the youths in a friendly non-judgmental environment that is equally free of stigma.

\section{ACKNOWLEDGMENTS}

Authors acknowledge the 400 Level medical students rotating through the Department of Community Medicine, Bowen University Teaching Hospital, Ogbomoso for assisting in data collection.

Funding: No funding sources

Conflict of interest: None declared

Ethical approval: The study was approved by the Institutional Ethics Committee 


\section{REFERENCES}

1. World Health Organization. Fact sheet; Adolescent pregnancy. Available at http://www.who.int/mediacentre/factsheets/fs364/en/ Accessed on $14^{\text {th }}$ August 2017.

2. UNDP/UNFPA/WHO/WORLDBANK. Special program of research development and training in human reproduction: social science initiative on quality of care and reproduction. 2003.

3. World Health Organization. Fact sheet; Preventing unsafe abortion. Available at http://www.who.int/mediacentre/factsheets/fs388/en/ Accessed on $14^{\text {th }}$ August 2017.

4. World Health Organization. Unsafe Abortion: global and regional estimates of the incidence of unsafe abortion and associated mortality in 2003. Geneva: World Health Organization. 2005.

5. Peltzer K. Early sexual debut and associated factors among in-school adolescents in eight African countries. Acta Paediatr. 2010;99(8):1242-7.

6. Federal Ministry of Health. Federal Office of Statistics (FOS). National demographic and health survey (NDHS). Lagos: Federal Office of Statistics. 2003

7. National Population Commisison, Federal Republic of Nigeria, Abuja Nigeria; ICF International, USA. Nigeria Demographic and Health Survey. 2013.

8. Chima UC, Lawoyin TO, Llika AL, Nnebue CC. Contraceptive knowledge and practice among secondary school students in military barracks in Nigeria. Nigerian J Clin Practice. 2016;19(2):182-8.

9. Orji EO, Esimai OA. Sexual behavior and contraceptive use among secondary school students in Ilesa South West Nigeria. J Obstet Gynecol. 2005;25(3):269-72.

10. Adetokunbo T, Oluwarotimi A, Abiola B, Adeniyi A, Dele O, Shitu L. Contraceptive knowledge and usage amongst female secondary school students in Lagos, South West Nigeria. J Pub Health Epidemol. 2011;3(1):34-7.

11. Iniabasi NI and Anthonia A. Adolescents and utilization of family planning services in rural community of Nigeria. Research on Humanities and Social Sciences. 2013;3(1):ISSN2222-2863.

12. Oyo State TESCOM. Oyo State Post-Primary School Teaching Service Commission. Available at http://oyotescom.org/oyotescom/schools.php. Accessed on $26^{\text {th }}$ August 2016.

13. Utuk NM, Abasiattai AM, Edu B. Awareness and practice of contraception among female secondary school students in Uyo, Nigeria. Ibom Med $\mathbf{J}$ 2017;10(2):1-5.

14. Anochie IC, Kepeme EE. Prevalence of sexual activity and outcome among female students in Port Harcourt, Nigeria. Afr J Reprod Health. 2001;5(20):63-7.

15. Gail BS, Lucy L, Huang B, Daniyaam CA, Theresa MZ, Paul S. Sexual behavior of adolescents in Nigeria: cross-sectional survey of secondary school students. BMJ. 2003;326(7379):15.

16. Ajuwon A, Olaleye A, Faromoju B, Ladipo O. Sexual behavior and experience of sexual coercion among secondary school students in three states in North Eastern Nigeria. BMC Public Health. 2005;6:310.

17. Nnebue CC, Chima U, Duru CB, Luka AL, Olaoyin TO. Determinants of age at sexual initiation among Nigerian adolescents: a study of secondary school students in a Military Barrack in Nigeria. Am J Med Sci Med. 2016;4(1):1-7

18. Idonije BO, Oluba OM, Otamere HO. A study on knowledge, attitude and practice of contraception among secondary school students in Ekpoma, Nigeria. JPCS. 2011;(2):22-7.

19. Odimegwu CO. Family planning attitude and use In Nigeria. International perspective on sexual and reproductive health. 1999;25(2):86-91.

Cite this article as: Idowu A, Aremu OA, Fehitola FO, Popoola GO. Knowledge, attitude and practice of contraception by female junior secondary school students in an urban community of Oyo-state, South west, Nigeria. Int J Reprod Contracept Obstet Gynecol 2017;6:4759-65. 